\title{
Influence of Different Pathways of Regeneration on Genetic and Phytochemical Instability of Curculigo orchioides
}

\author{
Parameswari Alagar*, Rahul Raveendran Nair ${ }^{1}$ and Ganesh Doss ${ }^{2}$ \\ Plant Genetic Improvement Laboratory, Sri Paramakalyani Centre for Environmental \\ Science, Manonmaniam Sundaranar University, Alwarkurichi P.O., Tirunelveli, Tamil \\ Nadu, 627414, India
}

Key words: Curculigo orchioides Genetic stability, Genetic marker, Multiple shoot regeneration

\begin{abstract}
Micropropagated plants of Curculigo orchioides Gaertn. through five different modes of regeneration were evaluated for their genetic stability and major flavanoids content that contribute to medicinal properties of the rhizome. Leaf explants that produced callus and bulbils have produced plantlets at a higher frequency. However, direct regeneration of plants from leaf tissues without intervening callus produced a low frequency of plantlets. Explants of rhizome produced healthy plantlets directly from the terminal part of the explant. Plantlets regenerated through five different modes of regeneration did not show any morphological variation. The duration of regeneration was varying from 60 to 145 days depending upon the type of the explant. Analysis of genomic DNA among the plantlets regenerated through five different modes of micropropagation revealed about $66 \%$ polymorphism. Major flavanoids such as rutin, ferulic acid, caffeic acid, quercitrin that contributed to medicinal properties of the rhizomes differed quantitatively among the plantlets regenerated through different pathways. Present study suggests that plantlets regenerated directly from the rhizome as well as from the leaf tips of in vitro grown plants are stable genetically and phytochemically.
\end{abstract}

\section{Introduction}

Curculigo orchioides Gaertn. is an important medicinal plant, belonging to the Hypoxidaceae. C. orichioides is commonly distributed in Indian plains, it is found in rock crevices and laterite soil up to an altitude of $2300 \mathrm{~m}$ (Asif 2012). The

*Author for correspondence: <parami_alagar@yahoo.co.in>. ${ }^{1}$ Department of Biotechnology, Vignan University, Vadlamudi P.O., Guntur, Andhra Pradesh, India, 522213. '2Department of Plant Biotechnology, School of Biotechnology, Madurai Kamaraj University, Palkalai Nagar P.O., Madurai, Tamil Nadu, India, 625021. 
tuberous roots of the $C$. orchioides contain significant amounts of flavones, glycosides, steroids and saponins and thus form an important source of herbal medicines for treating various diseases in India and China (Dhar et al. 1968, Xu et al. 1992). Natural populations of $C$. orchioides have been depleted due to overexploitation of rhizomes to meet the high demand for raw materials for preparation of indigenous herbal medicines and due to poor seed setting. This led to the declaration of the status of $C$. orchioides as endangered by IUCN (Augustine and Souza 1997). C. orchioides has been regarded as one of the most important tropical medicinal plants in primary health care and as such its conservation measures have been already stressed (Asif 2012). In view of this, plant tissue culture has been identified as one of the possible methods to conserve and restore endangered medicinal plant species (Mikulik 1999).

Flavonoids are an important class of plant secondary metabolites, possessing anti-allergic (Yamamoto et al. 2001), anti-inflammatory (Cazarolli et al. 2008), antioxidant (Cazarolli et al. 2008), anti-microbial (Cushnie et al. 2011) and anticancer (Cazarolli et al. 2008) properties. The major active component of rhizomes of C. orchioides was reported to be flavones (Asif 2012). Thin layer chromatography has been widely used for analyzing the contents in samples of plant origin (Bojic et al. 2013). However, the emergence of high performance thin layer chromatography (HPTLC) with a smaller average particle size of silica gel achieved ten-fold precision when compared to TLC (Bojic et al. 2013). HPTLC has been identified as an important tool for the quality management of herbal medicinal products owing to its high precision and strength (Shivatare et al. 2013). HPTLC has been used to analyze flavonoids contents in many plant species such as Launaea procumbens (Mishra et al. 2012), Aerva lanata (Mariswamy et al. 2012) and Solanum melongena (Satam et al. 2013).

Assessment of genetic fidelity of in vitro raised plants is important as somaclonal variation may occur due to the DNA methylations, chromosome rearrangements and point mutations (Phillips et al. 1994). Various methods have been used to check the genetic fidelity of micropropagated plants, substantiated by morphological descriptions, physiological observations, cytological and molecular studies (Gupta and Varshney 1999, Devarumath et al. 2007). Among these techniques, molecular methods are of utmost importance owing to high reliability and robustness. DNA markers such as random amplified polymorphic DNA (RAPD), restriction fragment length polymorphisms (RFLP) and inter simple sequence repeats (ISSR) are widely used in assessing the genetic purity of tissue culture raised plantlets. However, ISSR markers are mostly recommended for assessment of genetic purity of in vitro grown plants owing to their high reproducibility and precision (Zietkiewicz et al. 1994). ISSR markers have been 
Influence of Different Pathways of Regeneration

used for assessing genetic fidelity in various plant species such as Aloe vera (Rathore et al. 2011), Withania somnifera (Nayak et al. 2013) and Dendrocalamus asper (Singh et al. 2013).

The present study has three major objectives. First, developing a simple, reliable and reproducible micropropagation protocol for C. orchioides. Second, quantification of flavonoids present in the rhizome of in vitro grown plants raised through five different modes of propagation using HPTLC. Third, assessment of genetic fidelity of in vitro raised plantlets using inter simple sequsence repeat (ISSR) markers.

\section{Materials and Methods}

Healthy plants of Curculigo orchioides were collected from the wild forest of Wadakanchery village in Thrissur district of Kerala, Southern part of India. For proper maintenance, the experimental material was planted in earthen pots containing soil, sand and manure $(6: 1: 2)$. Plants were frequently watered and maintained under natural shade in the Botanical Garden of Sri Paramakalyani Centre for Excellence in Environmental Sciences, Manonmaniam Sundaranar University, Tirunelveli, Tamil Nadu. Leaf explants were surface sterilized with mercuric chloride $(0.1 \% \mathrm{w} / \mathrm{v})$ for $6 \mathrm{~min}$. The disinfected explants were washed with sterile distilled water to remove traces of sterilants after treatment. The leaves were cut into a number of $1 \mathrm{~cm}$ thick sections and used as explants during this study.

MS supplemented with sucrose (3\%) and agar $(0.7 \%)$ was the basic medium. Plant growth regulators in various combinations used. The $\mathrm{pH}$ of the media was adjusted to 5.8 prior to autoclaving at $121^{\circ} \mathrm{C}$. All the cultures were maintained at $25 \pm 2^{\circ} \mathrm{C}$ and kept under a $16 \mathrm{hrs}$ photoperiod provided by cool white fluorescent tubes with a light intensity of $40 \mu \mathrm{mol} \mathrm{m-2}$. To optimize callus induction, leaf explants of $C$. orchioides were cultured on MS fortified with BAP $(4.4-22.0 \mu \mathrm{M})$ and $\mathrm{Kn}(4.6-23.2 \mu \mathrm{M})$ either alone or in combination with $\mathrm{AgNO}_{3}(0.12 \mathrm{mM})$ and PG $(0.79 \mathrm{mM})$. Explant cultured initially for 40 days at different concentrations were observed for callus induction and recovered explants along with callus were transferred to fresh media of the same composition for shoot induction and maintained for 90 days. Data on percentage of callusing and number of shoots/culture were recorded and analyzed statistically using Duncan's new multiple range test. Level of significance was at $\mathrm{p}<0.05$.

The rhizomes of $C$. orchioides collected from the normal and micropropagated plants were cut into a small pieces before subjecting them to gradual drying at $35^{\circ} \mathrm{C}$ in a hot air oven for $24 \mathrm{hrs}$. The dried samples were made into fine powder using sterile mortar and pestle. The powder samples were mixed with $95 \%$ 
ethanol $1: 20(\mathrm{w} / \mathrm{v})$ and continuously stirred for 3 to 4 days to facilitate the extraction of bioactive compounds. Extracts were filtered through sterile Whatman filter paper (Himedia, India) and air dried. Samples were dissolved again with ethanol (95\%) and used for thin layer chromatography (TLC) and high performance thin layer chromatography (HPTLC).

TLC plates ( $20 \mathrm{~cm}$ length and $14 \mathrm{~cm}$ width) were prepared by thoroughly mixing the silica gel (Loba Chem. India) with sterile double distilled water $1: 3$ $(\mathrm{w} / \mathrm{v})$ and dried in hot air oven at $100^{\circ} \mathrm{C}$ for $30 \mathrm{~min}$. Ethanol extracts of samples measuring $100 \mu \mathrm{l}$ were drawn from various samples and spotted on silica gel plates. Benzene ( $\mathrm{CDH}$ Analytical reagent, India) was used as a solvent for chromatography analysis. Loaded samples on TLC plate were immersed at one end inside the development chamber containing the above solvent and left for 45 min for separation of compounds and stained with iodine vapour in an airtight chamber and TLC plates with visible spots were documented by photography using a digital camera. In addition, TLC plates were also exposed to UV to observe additional compounds emitting fluorescence under exposure to UV light.

To prepare a stock solution of gallic acid, $10 \mathrm{~g}$ of gallic acid (Loba Chemicals Pvt. Ltd, Mumbai, India) was dissolved in $100 \mathrm{ml}$ of $95 \%$ ethanol in a sterile volumetric flask. From this stock solution, seven different concentrations of gallic acid $(10,20,30,40,50,60$ and $70 \mu \mathrm{g} / \mathrm{ml})$ were prepared by drawing $1-7 \mathrm{ml}$ of aliquots from the stock solution and the final volume was adjusted to $10 \mathrm{ml}$ by adding 95\% ethanol. These solutions were used as standard following the protocol (Shrikumar et al. 2005).

Chromatography was performed on silica gel F254 HPTLC pre-coated plates. Samples were applied in the plates as band of $7 \mathrm{~mm}$ width using a Camag Linomat V sample (Switzerland) applicator at the distance of $14 \mathrm{~mm}$ from the edge of the plates. The mobile phase was constituted with ethyl acetate-acetic acid-formic acid-water $100: 11: 11: 27(\mathrm{v} / \mathrm{v} / \mathrm{v} / \mathrm{v})$. After development, plates were dried and derivatised in natural products - polyethylene glycol (NP-PEG) reagent. The fingerprints were evaluated at $366 \mathrm{~nm}$ in fluorescence mode with Win Cats and Video Scan software.

Genomic DNA was extracted from $25 \mathrm{mg}$ fresh leaf tissue (micropropagated plants through different pathways) (Table 1) using DNA isolation by following the protocol of manufacturer (Helini Biomolecules, Chennai, India). Fresh leaves (25 mg) were cut into smaller pieces and transferred to $1.5 \mathrm{ml}$ centrifuge tube and lysis buffer- $1(400 \mu \mathrm{l})$ and proteinase $\mathrm{K}(40 \mu \mathrm{l})$ were added before grinding the sample into a fine paste using micropestle. The mixture was incubated in water bath at $70^{\circ} \mathrm{C}$ for $10 \mathrm{~min}$ and allowed to attain room temperature. $3 \mathrm{M}$ sodium 
acetate $(100 \mu \mathrm{l})$ was added and mixed well. Samples were transferred into pure - fast column and centrifuged at $10000 \mathrm{rpm}$ for $1 \mathrm{~min}$. The supernatant was discarded and $500 \mu \mathrm{l}$ wash buffer 1 was added before centrifugation at 10000 rpm for $1 \mathrm{~min}$. This step was repeated twice with wash buffer $2(750 \mu \mathrm{l})$. After discarding the supernatant, the column was again centrifuged at $10000 \mathrm{rpm}$ for 1 min to remove ethanol. Elution Buffer $(100 \mu \mathrm{l})$ was added and centrifuged for 2 min and DNA samples were stored at $-20^{\circ} \mathrm{C}$.

Table 1. Regeneration of plantlets from rhizome and leaf tissues of Curculigo orchioides on MS supplemented with different growth regulators

\begin{tabular}{|c|c|c|c|c|}
\hline $\begin{array}{l}\text { Explant } \\
\text { type }\end{array}$ & $\begin{array}{l}\text { Optimized } \\
\text { media }\end{array}$ & $\begin{array}{l}\text { Mode of } \\
\text { regeneration }\end{array}$ & $\begin{array}{l}\text { No. of shoots/ } \\
\text { culture }\end{array}$ & $\begin{array}{l}\text { Duration of } \\
\text { regeneration }\end{array}$ \\
\hline Rhizome & MS+ BAP (1 mg/l) & Rhizome $>$ direct plantlets & 8.25 & $60-75 d$ \\
\hline Leaf & $\begin{array}{l}\mathrm{MS}+2,4-\mathrm{D}(1 \mathrm{mg} / \mathrm{l}) \\
+\mathrm{BAP}(5 \mathrm{mg} / \mathrm{l})\end{array}$ & Leaf $>$ callus $>$ plantlets & 28.32 & $90-115 d$ \\
\hline Leaf & $\begin{array}{l}\mathrm{MS}+\mathrm{BAP}(1 \mathrm{mg} / \mathrm{l}) \\
+\mathrm{AgNO}_{3}(20 \mathrm{mg} / \mathrm{l}) \\
+\mathrm{PG}(100 \mathrm{mg} / \mathrm{l})\end{array}$ & Leaf $>$ bulbils $>$ plantlets & 24.42 & $90-115 d$ \\
\hline $\begin{array}{l}\text { Leaf } \\
\text { Terminal } \\
\text { part of leaf } \\
\text { of in vitro plant }\end{array}$ & $\begin{array}{l}\mathrm{MS}+\mathrm{BAP}(1 \mathrm{mg} / \mathrm{l}) \\
\mathrm{MS}+\mathrm{BAP}(1 \mathrm{mg} / \mathrm{l}) \\
+\mathrm{AgNO}_{3}(20 \mathrm{mg} / \mathrm{l}) \\
+\mathrm{PG}(100 \mathrm{mg} / \mathrm{l})\end{array}$ & $\begin{array}{l}\text { Leaf }>\text { direct plantlets } \\
\text { Plantlets from terminal part } \\
\text { of leaf from in vitro plants }\end{array}$ & $\begin{array}{l}3.24 \\
2.25\end{array}$ & $\begin{array}{l}60-80 d \\
130-145 d\end{array}$ \\
\hline
\end{tabular}

Ten ISSR primers were used for assessment of genetic stability of the plantlets. PCR mixture was prepared by adding $25 \mu \mathrm{l}$ master mix $(10 \times$ Taq buffer, $2 \mathrm{mM} \mathrm{MgCl}$, 0.4 Mm dNTP mix, and 2U Taq DNA polymerase), ISSR primers $(1 \mu \mathrm{l}$ each), genomic DNA $(1 \mu \mathrm{l})$ and nuclease free water $(23 \mu \mathrm{l})$ to make final volume to $50 \mu \mathrm{l}$. The PCR was programmed as $94^{\circ} \mathrm{C}$ for $3 \mathrm{~min}$, followed by 35 cycles of $94^{\circ} \mathrm{C}$ for $1 \mathrm{~min}$ for a denaturation step, an annealing step of $1 \mathrm{~min}$ at $48^{\circ} \mathrm{C}$ and an extension step of $72^{\circ} \mathrm{C}$ for $2 \mathrm{~min}$, ending with $5 \mathrm{~min}$ at $72^{\circ} \mathrm{C}$. The PCR products were separated by electrophoresis in $2 \%$ agarose gel (Himedia, Mumbai, India) containing $0.1 \%$ ethidium bromide (Himedia, Mumbai, India) at a constant power of 50 volts and visualized under ultraviolet light. The molecular weights of various PCR products that were resolved in the agarose gel were compared with $1 \mathrm{~kb}$ plus DNA ladder. (Helini Quick Ref, Chennai, India).

Gels were visualized under UV transilluminator and photographed using the gel doc equipment (Alphal Mager gel documentation, USA). Among ten ISSR primers, four primers produced clear and reproducible bands. The common as well as unique bands were taken into consideration for determining the genetic variability of micropropagated plants developed through different modes of regeneration. 


\section{Results and Discussion}

The effect of BAP, $\mathrm{Kn}, \mathrm{AgNO}_{3}$ and PG on regeneration of bulbils from leaf explants of C. orchioides is presented in Table 2. In vitro regeneration of Curculigo orchioides was tested using rhizome, leaf derived callus, leaf derived bulbils, plantlets from leaf explant without intervention of callus and plantlets derived

Table 2. Effect of BAP, KN, $\mathrm{AgNO}_{3}$ and PG on bulbils formation and shoot regeneration from leaf explants of $C$. orchioides. Duration of culture 90 days.

\begin{tabular}{|c|c|c|c|c|c|c|c|c|}
\hline \multicolumn{4}{|c|}{ Concentration $(\mu \mathrm{M})$} & \multirow{2}{*}{$\begin{array}{c}\text { Sprouting } \\
(\%)\end{array}$} & \multirow{2}{*}{$\begin{array}{l}\text { No. of } \\
\text { bulbils/ } \\
\text { explant }\end{array}$} & \multirow{2}{*}{$\begin{array}{l}\text { bulbils } \\
\text { shoot/ } \\
\text { ratio }\end{array}$} & \multirow{2}{*}{$\begin{array}{l}\text { No. of } \\
\text { shoot/ } \\
\text { explant }\end{array}$} & \multirow{2}{*}{$\begin{array}{l}\text { Length of } \\
\text { longest } \\
\text { shoot }(\mathrm{cm})\end{array}$} \\
\hline BAP & $\mathrm{Kn}$ & $\mathrm{AgNO}_{3}$ & PG & & & & & \\
\hline- & - & - & - & $47.00^{\mathrm{d}}$ & $02.00^{\mathrm{d}}$ & $1.08^{\mathrm{b}}$ & $01.83 \mathrm{e}$ & $08.0^{\mathrm{b}}$ \\
\hline 04.4 & - & - & - & $65.00^{\mathrm{b}}$ & $03.58^{\mathrm{d}}$ & $2.47^{\mathrm{a}}$ & $01.58^{\mathrm{e}}$ & $04.9^{\mathrm{d}}$ \\
\hline- & 04.6 & - & - & $63.20^{\mathrm{b}}$ & $01.75^{\mathrm{d}}$ & $1.16^{\mathrm{b}}$ & $01.50^{\mathrm{e}}$ & $07.2^{\mathrm{bc}}$ \\
\hline- & - & 0.12 & - & $56.00^{c}$ & $06.58^{c}$ & $0.95^{\mathrm{bc}}$ & $09.16^{c}$ & $08.2^{\mathrm{b}}$ \\
\hline- & - & - & 0.79 & $44.70^{\mathrm{d}}$ & $10.00^{\mathrm{b}}$ & $1.04^{\mathrm{b}}$ & $06.41^{\mathrm{d}}$ & $06.8^{c}$ \\
\hline 04.4 & - & 0.12 & - & $73.30^{a}$ & $10.10^{\mathrm{b}}$ & $1.05^{\mathrm{b}}$ & $11.00^{\mathrm{b}}$ & $11.6^{\mathrm{a}}$ \\
\hline- & 04.6 & 0.12 & - & $69.50^{\mathrm{ab}}$ & $07.66^{\text {bc }}$ & $0.96^{\mathrm{bc}}$ & $09.75^{c}$ & $11.6^{\mathrm{a}}$ \\
\hline 04.4 & - & - & 0.79 & $54.70^{c}$ & $08.50^{\mathrm{bc}}$ & $1.04^{\mathrm{b}}$ & $07.75^{\mathrm{cd}}$ & $07.9 \mathrm{bc}$ \\
\hline- & 04.6 & - & 0.79 & $52.90^{c}$ & $08.00^{\mathrm{bc}}$ & $1.11^{\mathrm{b}}$ & $08.33^{\mathrm{cd}}$ & $08.1^{\mathrm{b}}$ \\
\hline 04.4 & - & 0.12 & 0.79 & $64.60^{\mathrm{b}}$ & $13.40^{\mathrm{a}}$ & $1.29^{b}$ & $07.08^{\mathrm{d}}$ & $07.8^{\mathrm{bc}}$ \\
\hline- & 04.6 & 0.12 & 0.79 & $64.50^{\mathrm{b}}$ & $08.00^{\mathrm{bc}}$ & $0.93^{\mathrm{bc}}$ & $14.60^{\mathrm{a}}$ & $08.8^{\mathrm{b}}$ \\
\hline 22.0 & - & 0.12 & - & $44.40^{\mathrm{d}}$ & $08.33^{\text {bc }}$ & $1.03^{b}$ & $08.00^{\mathrm{cd}}$ & $08.5^{\mathrm{b}}$ \\
\hline- & 23.2 & 0.12 & 0.79 & $43.30^{\mathrm{d}}$ & $07.83^{\mathrm{bc}}$ & $1.08^{\mathrm{b}}$ & $08.00^{\mathrm{cd}}$ & $08.5^{\mathrm{b}}$ \\
\hline
\end{tabular}

Data represents the mean values of three replications, each consists of 30 explants. Mean values within each column followed by the same letter in superscripts are not differing significantly $(\mathrm{P} \leq$ 0.05: Duncun's New Multiple Range Test).

from terminal part of in vitro derived plants from rhizome (Fig. 1). The percentage of sprouting explants ranged from 43.3 - 73.3\%. Of the 12 combinations of media tested, $4.4 \mu \mathrm{M}$ BAP in combination with $0.12 \mathrm{mM} \mathrm{AgNO}_{3}$ induced the highest frequency of sprouting with $73.3 \%$. In this concentration, maximum number of bulbils per explant (10.1) was induced (Fig. 2). Maximum number of microshoots (11 shoots /explant) could be induced at this combination with the highest shoot length $(11.6 \mathrm{~cm})$. The percentage of response was significantly reduced to $43.3 \%$ when leaf explants were cultured in medium containing $23.2 \mu \mathrm{M} \mathrm{Kn}$ in combination with $0.12 \mathrm{mM} \mathrm{AgNO}_{3}$ and $0.79 \mathrm{mM}$ PG (Fig. 3). Leaf explants often produced more number of bulbils (7.83 bulbils/ explant) and microshoots (8 shoot/explant) with longer shoot $(8.5 \mathrm{~cm})$. Although the explants cultured in MS showed $47 \%$ sprouting, the number of bulbils and shoot production was significantly lower than the treatments. The ratio of bulbils 
to shoot development ranged from 0.93 - 2.47 depending upon the presence of various hormones in combination with $\mathrm{PG}$ and $\mathrm{AgNO}_{3}$. This experiment clearly showed that BAP at $4.4 \mu \mathrm{M}$ in combination with $0.12 \mathrm{mM} \mathrm{AgNO}_{3}$ was suitable for regeneration of a large number of plantlets in C. Orchioides (Fig. 4). Almost $80 \%$ of the fully grown plantlets were hardened and transferred to field (Fig. 5). No separate experiment was conducted for rooting as root induction was observed simultaneously with induction of shoots.

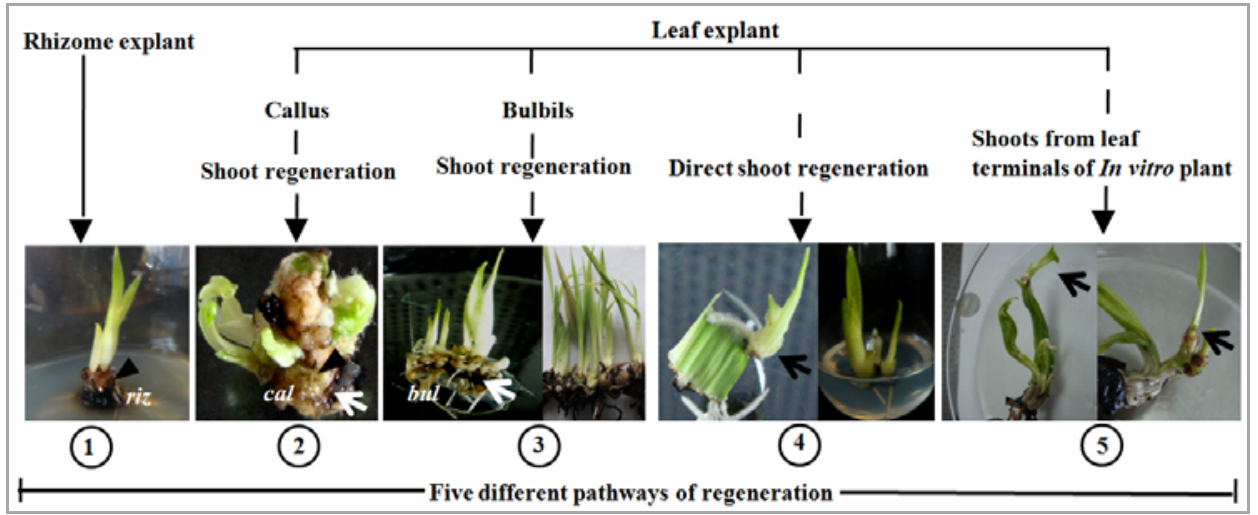

Fig. 1. Regeneration of C. orchioides from the rhizome (1), leaf derived callus (2), leaf derived bulbils (3), plantlets derived from leaf explants without the intervention of callus (4) and plantlets derived from the terminal parts of in vitro derived plants from rhizome (5). Arrow mark indicates rhizome, callus and bulbils and abbreviated as rhiz, cal and bul, respectively in the figure.

Methanolic extracts prepared from the rhizome of plantlets regenerated from different pathways showed interesting results. It was observed that all the samples contained same compounds as revealed by the TLC experiments. However, plantlets regenerated from pathway 2 (plantlets derived from callus of explants) showed differential banding pattern as compared to plantlets regenerated from other pathways of micropropagation. It was observed that rhizome of plantlets obtained from pathway 2 did not reveal the presence of thick TLC band at one end of the TLC plate whereas, in other samples, bands with a similar Rf value $(0.18,0.20,0.36,0.39$ and 0.71$)$ was observed. This clearly indicates that the plantlets that regenerated from pathway 2 show variation with regard to its phytochemical constituents. In the remainder, hytochemicals were found to be common among the plantlets that regenerated from pathways: 3, 4 and 5 and found similar to that of the control plants (Fig. 6).

The chromatogram with calibration data obtained from the rhizome extract of plantlets regenerated through five different pathways of micropropagation have been shown in Fig. 7. The data on quantification of major flavanoids present in the rhizome extract of various experimental materials was presented 
(Table 3). Four flavanoids such as rutin, ferulic acid, caffeic acid and quercitrin were found in the rhizome of various samples. Maximum quantity of rutin with $5.44 \mu \mathrm{g} / \mathrm{g}$ and $5.55 \mu \mathrm{g} / \mathrm{g}$ of rhizome extract was observed in plantlets regenerated from terminal part of the leaves in the in vitro grown plantlets (pathway 5) and directly from the rhizome, respectively (pathway 1). This quantity was comparable with the quantity of rutin present in the normal plant. The quantity
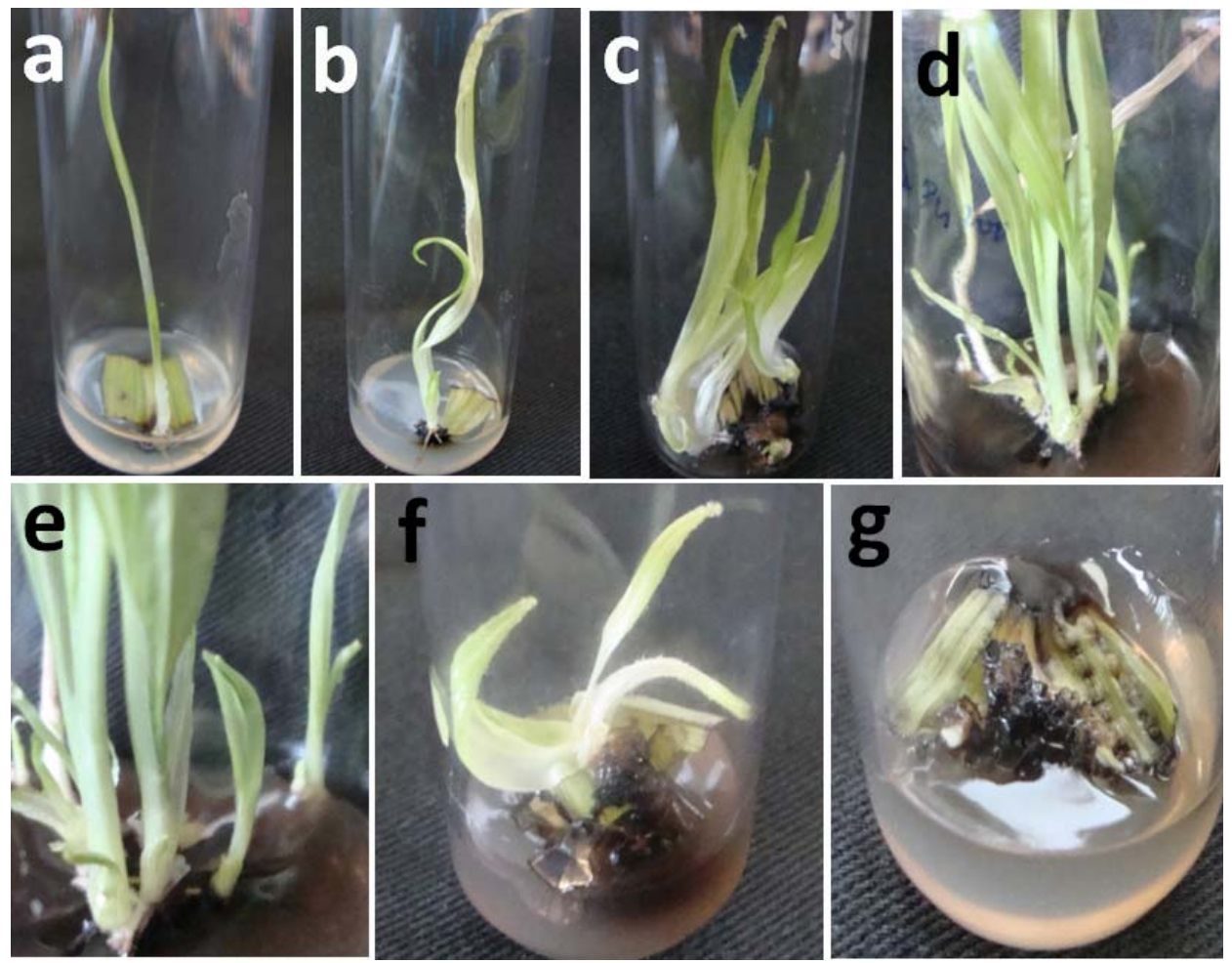

Fig. 2. Influence of various concentrations of $\mathrm{AgNO}_{3}$ on regeneration of bulbils and microshoots from leaf explants of $C$. orchioides: (a) development of long shoots on the MS containing 4.4 $\mu \mathrm{M}$ BAP (control), (b) regeneration of lean and lanky shoots on medium containing $4.4 \mu \mathrm{M}$ BAP and 0.06 $\mathrm{mM} \mathrm{AgNO}_{3}$, (c) leaf segments producing healthy multiple shoots in presence of $4.4 \mu \mathrm{M}$ BAP and $0.12 \mathrm{mM} \mathrm{AgNO}_{3},(\mathrm{~d} \& \mathrm{e})$ regeneration of multiple shoots from leaf explants on medium containing $4.4 \mu \mathrm{M}$ BAP and $0.18 \mathrm{mM} \mathrm{AgNO}_{3}$, (f \& g) inhibition of healthy shoot development in leaf explants at higher concentrations of $\mathrm{AgNO}_{3}(0.24 \mathrm{mM}$ and $0.29 \mathrm{mM})$.

of rutin was significantly lower in other samples. A similar tendency was observed with respect to ferulic acid, caffeic acid and quercitrin. The results of this experiment clearly show that rutin contributes to the major part of flavanoids compared to ferulic acid, caffeic acid and quercitrin. This experiment also showed that the micropropagated plants were similar to that of normal plant with respect to major flavanoids constituents as revealed by the HPTLC 
profile. It is expected that HPTLC can be used for analyzing the medicinal property of $C$. orchioides through quantification of all the four flavanoids constituents present in the rhizome extract of $C$. orchioides.

Table 3. Quantity of flavanoids from the rhizome extracts of Curculigo orchioides regenerated from different pathways viz. (1) plantlets regenerated directly from rhizome; (2) plantlets derived from callus of leaf explant; (3) plantlets derived from bulbils of leaf explant; (4) plantlets from leaf explant without intervention of callus; (5) plantlets derived from the terminal parts of in vitro derived plants from rhizome.

\begin{tabular}{clllll}
\hline & & \multicolumn{4}{c}{ Flavanoids $(\mu \mathrm{g} / \mathrm{g})$} \\
\cline { 3 - 6 } $\begin{array}{l}\text { Regeneration } \\
\text { pathway }\end{array}$ & $\begin{array}{l}\text { Gallic acid } \\
\text { (standard) }\end{array}$ & Rutin & Ferulic acid & Caffeic acid & Quercitrin \\
\hline Control & $12.27^{\mathrm{b}}$ & $5.53^{\mathrm{a}}$ & $0.368^{\mathrm{a}}$ & $0.064^{\mathrm{a}}$ & $0.171^{\mathrm{a}}$ \\
1 & $13.08^{\mathrm{a}}$ & $5.44^{\mathrm{b}}$ & $0.361^{\mathrm{ab}}$ & $0.062^{\mathrm{ab}}$ & $0.170^{\mathrm{a}}$ \\
2 & $10.25^{\mathrm{d}}$ & $0.62^{\mathrm{e}}$ & $0.121^{\mathrm{e}}$ & $0.018^{\mathrm{c}}$ & $0.031^{\mathrm{c}}$ \\
3 & $11.75^{\mathrm{c}}$ & $3.49^{\mathrm{c}}$ & $0.164^{\mathrm{d}}$ & $0.011^{\mathrm{c}}$ & $0.038^{\mathrm{c}}$ \\
4 & $12.25^{\mathrm{b}}$ & $2.19^{\mathrm{d}}$ & $0.310^{\mathrm{c}}$ & $0.011^{\mathrm{c}}$ & $0.067^{\mathrm{b}}$ \\
5 & $12.75^{\mathrm{b}}$ & $5.55^{\mathrm{a}}$ & $0.351^{\mathrm{b}}$ & $0.055^{\mathrm{b}}$ & $0.171^{\mathrm{a}}$ \\
\hline
\end{tabular}

Tukey's HSD (Honestly Significant Difference) test; Figures with the same superscripts are not differing significantly.
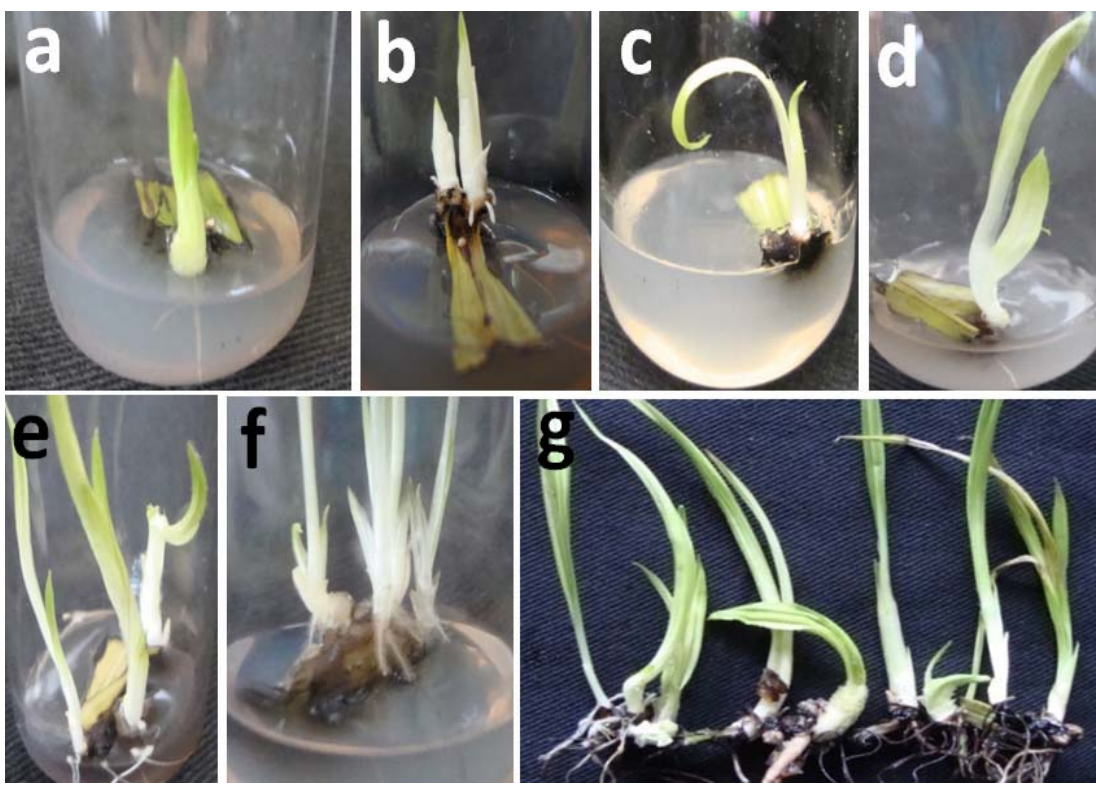

Fig. 3. Influence of PG on regeneration of bulbils and microshoots from leaf explants of $C$. orchioides: a) leaf explant showing shoot development in MS containing 4.4 $\mu \mathrm{M}$ BAP, (b-d) responding leaf segments showing poor shoot regeneration on medium containing $4.4 \mu \mathrm{M}$ BAP and PG (0.16-0.47 $\mathrm{mM}$ ), (e) regeneration of multiple shoots at $4.4 \mu \mathrm{M}$ BAP and $0.63 \mathrm{mM}$ PG, (f \& g) induction on bulbils and healthy shoots on medium containing $4.4 \mu \mathrm{M}$ BAP with $0.79 \mathrm{mM}$ PG. 

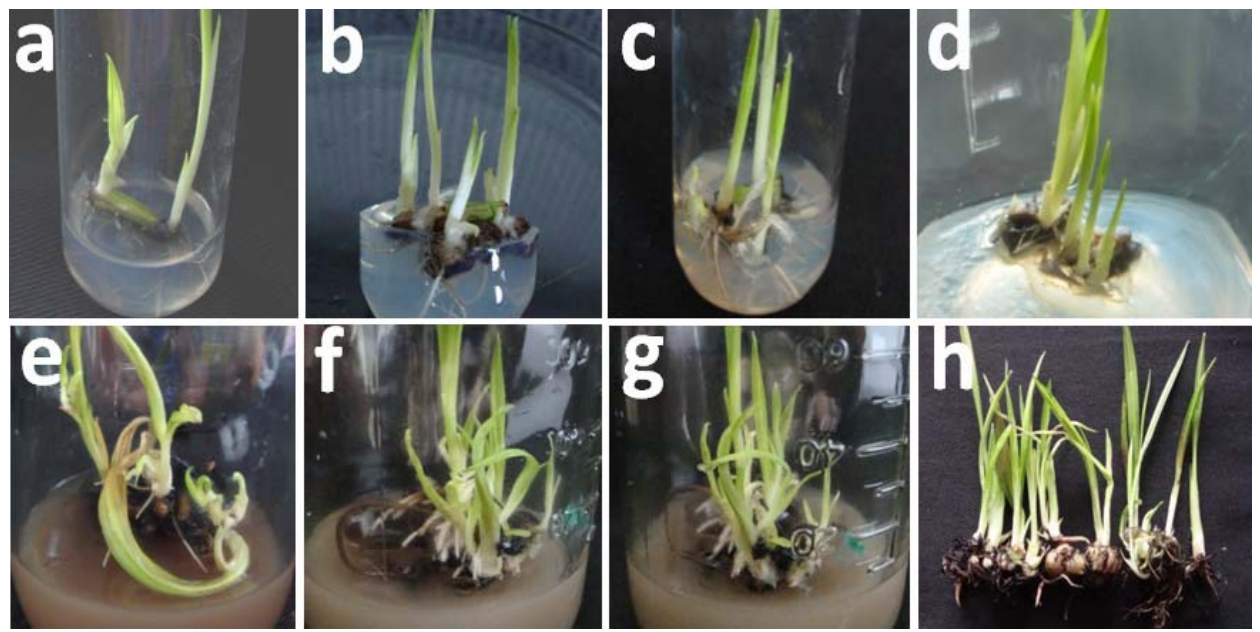

Fig. 4. Combined effect of $\mathrm{BAP}, \mathrm{Kn}, \mathrm{AgNO}_{3}$ and $\mathrm{PG}$ on regeneration of bulbils and microshoots from leaf explants of $C$. orchioides: a) response of leaf explants on MS (control), (b) regeneration of multiple shoots on medium containing $4.4 \mu \mathrm{M} \mathrm{BAP}$, (c) leaf explants showing the regeneration of shoots with initiation of roots in presence of $4.6 \mu \mathrm{M} \mathrm{Kn}$, (d) healthy multiple shoot induction on medium containing $4.4 \mu \mathrm{M}$ BAP and $0.12 \mathrm{mM} \mathrm{AgNO}_{3}$, (e) regeneration on multiple shoots on the medium with $4.6 \mu \mathrm{M} \mathrm{Kn}$ and $0.12 \mathrm{mM} \mathrm{AgNO}_{3}$, (f \& g) development of high frequency multiple shoots on the medium containing $4.4 \mu \mathrm{M}$ BAP, $4.6 \mu \mathrm{M} \mathrm{Kn}, 0.12 \mathrm{mM} \mathrm{AgNO} 3$ and $0.79 \mathrm{mM} \mathrm{PG}$, (h) regenerated plantlets showing healthy bulbils and shoots.

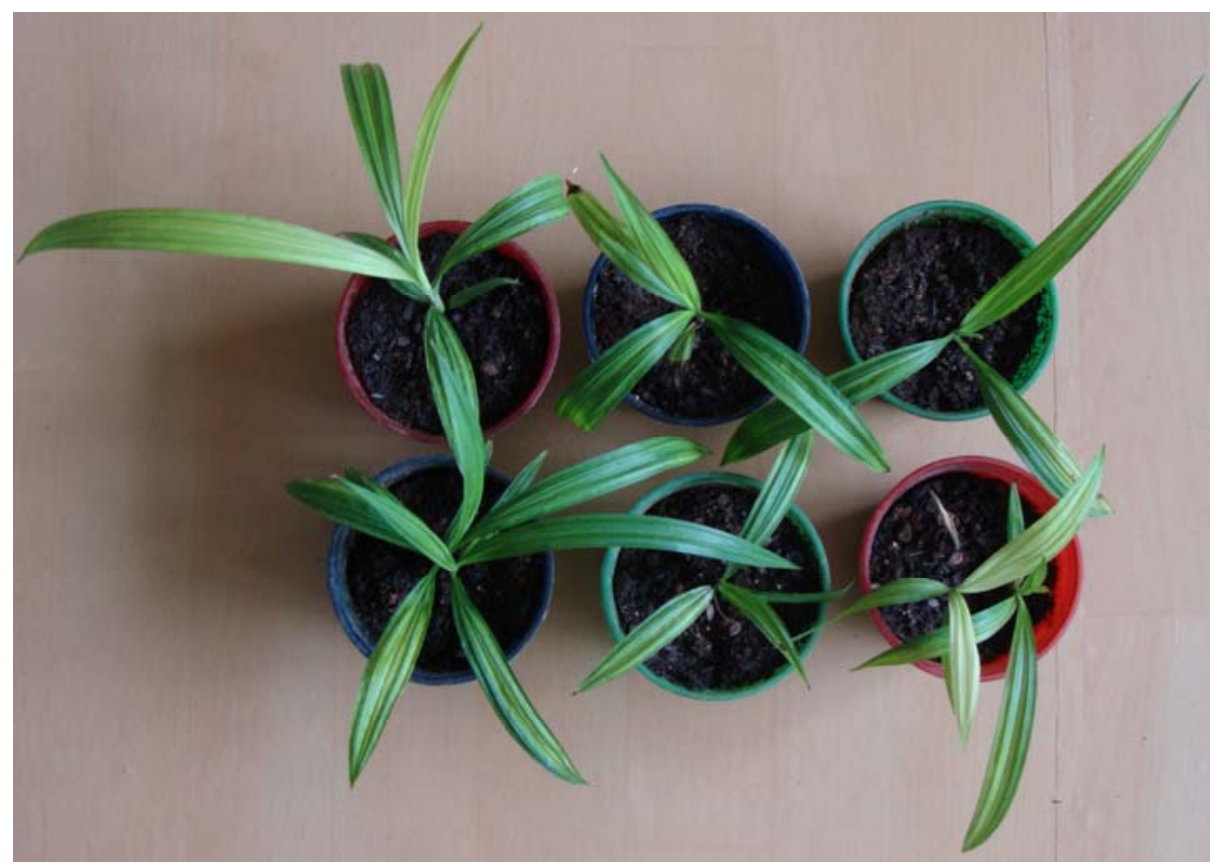

Fig. 5. Hardened plantlets of in vitro regenerated C. orchioides. 
In order to determine the genetic fidelity of the micropropagated plantlets regenerated from five different pathways (Fig. 8), about 10 ISSR primers were tested and the following results were obtained. Out of 10 primers, only 4 amplified the genomic DNA of $C$. orchioides. The number of amplified ISSR bands varied from $4-8$ depending upon the primers used. 8 - 12 monomorphic bands and $4-8$ polymorphic bands were observed in the agarose gel electrophoresis. The size of ISSR PCR products were varying from $1-2 \mathrm{~kb}$ in size. Of the 10 primers, one of the primers, namely Co-ISSR-09 could amplify a maximum number of scorable bands ranging from 6 - 10 in all the five samples. This primer produced 4 distinct polymorphic bands across the five samples. In general, most of the bands were monomorphic in nature, indicating the genetic similarities of micropropagated plants with the control.

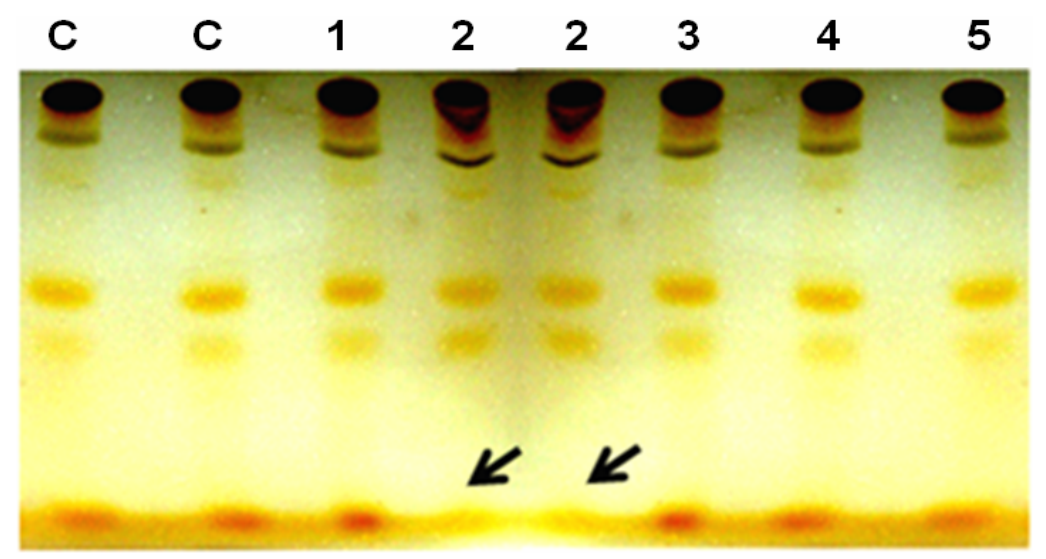

Fig. 6. Thin layer chromatogram from the extract of rhizomes of micropropagated plants of Curculigo orchioides regenerated through different pathways of micropropagation viz. (1) plantlets regenerated directly from the rhizome; (2) plantlets derived from callus of leaf explants; (3) plantlets derived from bulbils of leaf explants; (4) plantlets from leaf explants without intervention of callus; 5) plantlets derived from the terminal part of in vitro derived plants from rhizome. Ccontrol plant; arrow indicates the absence of one of the compounds in the rhizome of plants regenerated from callus of leaf explants.

In this study, a combination of cytokinins (BAP and $\mathrm{Kn}$ ) and adjuvant $\left(\mathrm{AgNO}_{3}\right.$ and $\left.\mathrm{PG}\right)$ was found to enhance the formation of bulbils and shoot proliferation in the leaf explants of $C$. orchioides. Presence of $4.4 \mu \mathrm{M}$ BAP in combination with $0.12 \mathrm{mM} \mathrm{AgNO}_{3}$ was found to be suitable for induction of maximum regeneration of bulbils in addition to faster shoot regeneration. But combination of $4.4 \mu \mathrm{M}$ BAP, $0.12 \mathrm{mM} \mathrm{AgNO}_{3}$ and $0.79 \mathrm{mM}$ PG had induced the highest mean number of healthy bulbils per explant (13.4) but number of shoots produced in this combination was comparatively lesser than the previous treatment. The synergistic effect of $\mathrm{AgNO}_{3}$ with $\mathrm{BAP}$ and $\mathrm{Kn}$ on enhancement of 
shoot regeneration was reported in a number of species such as Brassica campestris (Chi and Pua 1989) and Nicotiana plumbaginifolia (Purnhauser et al. 1987). The present study revealed that presence of $0.12 \mathrm{mM} \mathrm{AgNO}_{3}$ in combination with BAP and $\mathrm{Kn}$ enhanced a greater number of bulbils as well as multiple shoot regeneration in leaf explants of $C$. orchioides. Therefore, it could be concluded that $\mathrm{AgNO}_{3}$ acted synergistically with BAP and $\mathrm{Kn}$ to enhance the shoot proliferation in leaf explants of $C$. orchioides.

Table 4. Polymorphism of micropropagated plantlets of $C$. orchioides from the rhizome (1), leaf derived callus (2), leaf derived bulbils (3), plantlets from leaf the explants without intervenetion of callus (4) and plantlets derived from the terminal parts of the in vitro derived plants from the rhizome (5).

\begin{tabular}{|c|c|c|c|c|c|c|c|c|c|}
\hline \multirow{2}{*}{$\begin{array}{l}\text { ISSR } \\
\text { Primers } \\
\left(5^{\prime}-3^{\prime}\right)\end{array}$} & \multirow[t]{2}{*}{$\begin{array}{l}\text { Primer } \\
\text { sequences }\end{array}$} & \multicolumn{5}{|c|}{$\begin{array}{l}\text { No. of bands in the rhizome and } \\
\text { leaf derived micropropagated plants }\end{array}$} & \multirow{2}{*}{$\begin{array}{l}\text { Mono- } \\
\text { morphic } \\
\text { bands }\end{array}$} & \multirow{2}{*}{$\begin{array}{l}\text { Poly- } \\
\text { morphic } \\
\text { bands }\end{array}$} & \multirow{2}{*}{$\begin{array}{l}\text { Size } \\
\text { range } \\
(\mathrm{Kb})\end{array}$} \\
\hline & & 1 & 2 & 3 & 4 & 5 & & & \\
\hline Co-ISSR-1 & $(\mathrm{GT})_{6} \mathrm{GG}$ & NA & NA & NA & NA & NA & -- & -- & -- \\
\hline Co-ISSR-2 & $(\mathrm{GA})_{6} \mathrm{CC}$ & NA & NA & NA & NA & NA & -- & -- & -- \\
\hline Co-ISSR-3 & $(\mathrm{GT})_{6} \mathrm{CC}$ & 4 & 6 & 4 & 4 & 4 & 4 & $2(33.3 \%)$ & $1.0-1.5$ \\
\hline Co-ISSR-4 & $(\mathrm{CT})_{8} \mathrm{AC}$ & NA & NA & NA & NA & NA & -- & -- & -- \\
\hline Co-ISSR-5 & (CT) ${ }_{8} \mathrm{GC}$ & 4 & 6 & 4 & 4 & 4 & 4 & $2(33.3 \%)$ & $1.0-1.5$ \\
\hline Co-ISSR-6 & $(\mathrm{CA})_{6} \mathrm{AC}$ & NA & NA & NA & NA & NA & -- & -- & -- \\
\hline Co-ISSR-7 & $(\mathrm{CA})_{6} \mathrm{GG}$ & 6 & 8 & 6 & 6 & 6 & 6 & $2(25.0 \%)$ & $1.0-2.0$ \\
\hline Co-ISSR-8 & $(\mathrm{GA})_{6} \mathrm{GG}$ & NA & NA & NA & NA & NA & -- & -- & -- \\
\hline Co-ISSR-9 & (AC)8TG & 8 & 6 & 8 & 10 & 10 & 6 & $4(66.6 \%)$ & $0.7-2.0$ \\
\hline Co-ISSR-10 & $(\mathrm{GAG})_{5} \mathrm{GC}$ & NA & NA & NA & NA & NA & -- & -- & -- \\
\hline
\end{tabular}

Thin layer chromatography of rhizome extracts obtained from the normal and micropropagated plants of five different pathways revealed five prominent bands in case of plantlets obtained from pathways 1, 3, 4 and 5 with respective $\mathrm{Rf}$ values $(0.18,0.20,0.36,0.39$ and 0.71$)$. These bands were comparable with control as they were found to have similar Rf values. However, rhizomes from plantlets regenerated through pathway 2 showed only four prominent bands similar to the above but with the absence of one band with the RF values of 0.71 . A similar technique was employed for determining the phytochemical properties of root extract of micropropagated plants of Withania somnifera confirming that the micropropagated plants were similar to the control (D'Silva 2009). More recently, the methanolic extract of micropropagated plants of Andrographis paniculata was evaluated for its phytochemical property using TLC method (Ahmed et al. 2012). The present study proves that TLC is a simple and cost effective method to evaluate the presence of major phytochemical in C. orchioides. 


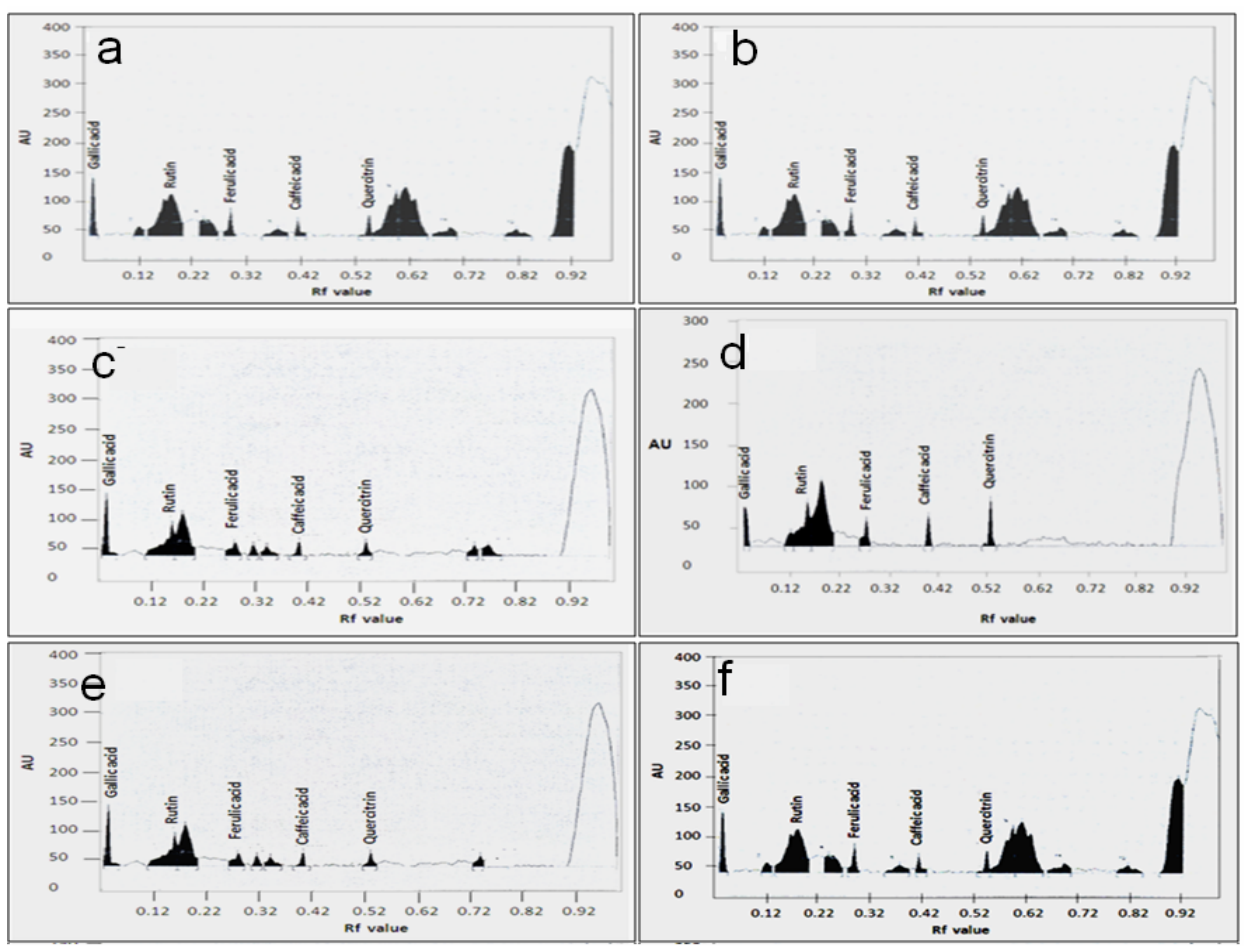

Fig. 7. HPTLC chromatograms of rhizome extract of Curculigo orchioides regenerated through different pathways of micropropagation viz. (a) chromatogram showing the flavanoids of rhizome extract of C. orchioides (control), plantlets regenerated directly from rhizome (pathway 1), (b) plantlets derived from callus of leaf explant (pathway 2), (c) plantlets derived from bulbils of leaf explant (pathway 3), (d) plantlets from leaf explant without intervention of callus (pathway 4), e) plantlets derived from terminal part of in vitro derived plants from rhizome (pathway 5).

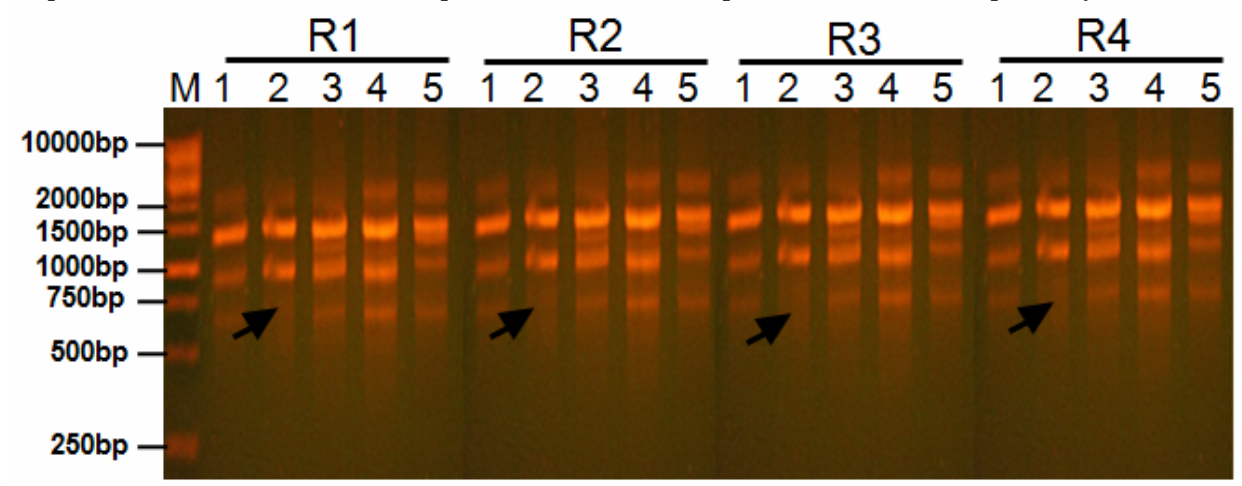

Fig. 8. Inter simple sequence repeats of four replicated individual plants of Curculigo orchioides regenerated from five different pathways of micropropagation using ISSR primer (AC)sTG: (1) Plantlets regenerated directly from rhizome, (2) plantlets derived from callus of leaf explants, (3) plantlets derived from bulbils of leaf explants, (4) plantlets from leaf explants without intervention of callus, (5) plantlets derived from terminal part of in vitro derived plants from rhizome. 
In the present study, HPTLC finger prints developed from the rhizome of plantlets obtained through five different pathways of micropropagation showed similarities with respect to their major phytochemical constituents (Table 3). HPTLC chromatographic finger print displayed the various types of flavanoids such as rutin, ferulic acid, caffeic acid and quercitrin from the rhizome of all the samples. However, the quantity of these compounds was higher in the rhizomes of plantlets regenerated from pathways 1 and 5 and comparable with control. Among the four flavanoids, the quantity of rutin was higher in the rhizome of plantlets regenerated from pathways 1 and 5 (5.44 and 5.55). It was reported that the percentage of rutin was higher than that of quercitrin in the leaves of Tephrosia purpurea (Jain et al. 2009). The present study concluded that rhizomes of plantlets regenerated plants from five different pathways of micropropagation of C. orchioides contained similar flavanoids as mother plant.

In order to determine the genetic fidelity of plantlets regenerated from five different pathways of the micropropagation in C. orchioides, 10 ISSR primers were designed based on the availability of primers in closely related species (Table 4). Of the ten ISSR primers, four primers (Co-ISSR-03, Co-ISSR-05, Co-ISSR-07 and Co-ISSR-09) produced the maximum number of scorable bands (10), monomorphic bands (6) and polymorphic bands (4). It was reported that ISSR regions lying within the range of microsatellite repeats have a higher capacity to reveal polymorphism and offer great potential to determine intragenomic and intergenomic diversity as compared to other arbitrary primers such as RAPDs (Zietkiewicz et al. 1994). The ISSR primers are now proven to be much more efficient in assessing the genetic integrity among clonally propagated plants as reported by many workers in different species (Zietkiewicz et al. 1994, Bhatia et al. 2009, Mohanty et al. 2010, Bhatia et al. 2011). Martins et al. (2004) reported genetic homogeneity of almond plantlets regenerated $t$ hrough auxiliary branching after $4-6$ years of in vitro multiplication.

Homogeneity in amplification profile was reported for all micropropagated plantlets in Swertia chirayita through ISSR marker assay (Joshi and Dhawan 2007). ISSR markers reportedly reveal substantially higher levels of polymorphism than RFLP markers in maize (Kantety et al. 1995) and are also useful for detecting somaclonal variation among micropropagated plants of coffee (Rani et al. 2000). ISSR analysis exhibited monomorphism among all micropropagated plants of Rauvolfia serpentine and they were found to be genetically stable (Saravanan et al. 2011). But the present finding reveals that the micropropagated plants from five different pathways of $C$. orchioides produced the maximum number of monomorphic bands, revealing their genetic fidelity. 
Influence of Different Pathways of Regeneration

\section{Acknowledgement}

This study is a part of the first author's (PA) Ph.D. work and she gratefully acknowledges the authority of Department of Biotechnology, SPKCES, MS University for providing facilities for this piece of research work.

\section{References}

Asif M (2012) A review on phytochemical and ethnopharmacological activities of Curculigo orchioides. Mu. J. Pharm. Sci. 39(3-4): 1-10.

Augustine AC and Souza LD (1997) Regeneration of an anticancer herb Curculigo orchioides Gaertn. In Vitro Cell Dev. Biol. Plant 33: 111 - 113.

Ahmad R, Sharma VK and Rai AKRD, Shivananda BG (2007). Production of lignans in callus culture of Podophyllum hexandrum. Trop. J. Pharm. Res. 6(4): 803 - 808.

Bhatia R, Singh KP, Jhang T, Sharma TR (2009) Assessment of genetic fidelity of micropropagated gerbera plants by ISSR markers. Sci. Hort. 11(2): 208-211.

Bhatia R, Singh KP, Sharma TR and Jhang T (2011). Evaluation of the genetic fidelity of in vitro propagated gerbera (Gerbera jamesonii Bolus) using DNA-based markers. Plant Cell Tiss. Org. 104: 131-135.

Bojic M, Haas VS, 2 Šaric D and Males Z (2013) Determination of flavonoids, phenolic acids, and xanthines in mate tea (Ilex paraguariensis St.-Hil.). J. Anal. Methods Chem. dx.doi.org/10.1155/2013/658596

Cazarolli LH, Zanatta L, Alberton EH, Figueiredo MS, Folador P, Damazio RG, Pizzolatti MG, and Silva FR (2008) "Flavonoids: Prospective drug candidates". Mini-Rev.Med. Chem. 8(13): 1429-1440

Chi GL and Pua EC (1989) Ethylene inhibitors enhanced de-novo shoot regeneration from cotyledons of Brassica compestris ssp. Chinensis (Chinese cabbage) in vitro. Plant Sci. 64: 243-250.

Cushnie TPT and Lamb AJ (2011) Recent advances in understanding the antibacterial properties of flavonoids. Int. J. Antimicrob. Agents 38(2): 99-107.

Devarumath RM, Doule RB, Kawar PG, Naikebawane SB and Nerkar YS (2007) Field performance and RAPD analysis to evaluate genetic fidelity of tissue culture raised plants vis-a-vis conventional setts derived plants of Sugarcane. Sugar Tech. 9(1): 1722.

Dhar LM, Dhar MM, Dhawan BN and Ray C (1968) Screening of Indian plants for biological activity, Part I. Indian J. Exp. Biol. 6: 232-247.

D'Silva MAN and Senarath WTPSK (2009) In vitro mass propagation and greenhouse establishment of Withania somnifera (L.) Dunal (Solanaceae) and comparison of growth and chemical compounds of tissue cultured and seed raised plants. J. Natn. Sci. Foundation Sri Lanka 37(4): 249-255.

Gupta PK and Varshney RK (1999) Molecular markers for genetic fidelity during micropropagtion and germplasm conservation. Curr. Sci. 76: 1308-1310. 
Jain A, Lodhi S and Singhai AK (2009) Simultaneous estimation of quercetin and rutin in Tephrosia purpurea Pers by high performance thin layer chromatography. Asian J. Trad. Med. 4(3): 104-109.

Joshi P and Dhawan V (2007) Assessment of genetic fidelity of micropropagated Swertia chirayita plantlets by ISSR marker assey. Biol. Plant 51(1): 22 -26.

Kantety RV, Zeng XP, Bennetzen JL and Zehr BE (1995) Assessment of genetic diversity in dent and popcorn (Zea mays L.) inbred lines using inter-simple sequence repeat (ISSR) amplific- ation. Mol. Breeding 1: 365 -373.

Martins M, Sarmento D and Oliveira MM (2004) Genetic stability of micropropagated almond plantlets as assessed by RAPD and ISSR markers. Plant Cell Rep. 23: 492-496.

Mikulik J (1999) Propagation of endangered plant species by tissue cultures. Acta Univ. Palacki. Olomuc. Fac. Rer. Nat. Biol. 37: 27-33.

Mishra GJ, Reddy MN and Rana JS (2012). Isolation of Flavonoid Constituent from Launaea procumbens Roxb. by Preparative HPTLC Method. IOSR J. Pharm. 2(4): 5-11.

Mohanty S, Joshi RK, Subudhi E, Sahoo S and Nayak S (2010) Assessment of genetic stability of micropropagated Curcuma caesia through cytophotometric and molecular analysis. Cytologia 75(1): 73-81.

Nayak SA, Kumar S, Satapathy K, Moharana A, Behera B, Barik DP, Acharya L, Mohapatra PK, Jena PK and Naik SK (2013) In vitro regeneration from cotyledonary nodes of Withania somnifera (L.) Dunal and assessment of clonal fidelity using RAPD and ISSR markers. Acta Physiol. Plant 35(1). DOI: 10.1007/s11738-012-1063-2

Phillips RL, Kaeppler SM and Olhoft P (1994) Genetic instability of plant tissue cultures: Breakdown of normal controls. Proc. Nat. Acad. Sci. USA 91: 5222-5226.

Purnhauser L, Medgyesy P, Czako M, Dix PJ and Marton L (1987) Stimulation of shoot regeneration in Triticum aestivum and Nicotiana plumbaginifolia Viv. tissue cultures using the ethylene inhibitor AgNO3. Plant Cell Rep. 6: 1-4.

Rani V, Singh KP, Shiran B, Nandy S, Goel S, Devarumath RM, Sreenath HL and Raina SN (2000) Evidence for new nuclear and mitochondrial genome organizations among high- frequency somatic embryogenesis-derived plants of allotetraploid Coffea arabica L. (Rubiaceae). Plant Cell Rep. 19: 1013-1020.

Rathore MS, Chikara J, Mastan SG, Rahman H, Anand KGV and Shekhawat NS (2011a) Assessment of genetic stability and instability of tissue culture-propagated plantlets of Aloe vera L by RAPD and ISSR Markers. Appl. Biochem. Biotechnol. 165: 1356-1365

Saravanan S, Sarvesan R and Vinod MS (2011) Identification of DNA elements involved in somaclonal variants of Rauvolfia serpentina (L.) arising from indirect organogenesis as evaluated by ISSR analysis. Indian J. Sci. Technol. 4(10): 1241- 1245.

Satam NK, Parab LS and Bhoir SI (2013) HPTLC finger print analysis and antioxidant activity of flavonoid fraction of Solanum melongena Linn fruit. Int J. Pharm. Sci. 5(3): 734-740.

Mariswamy Y, Gnaraj WE and Antonisamy JM (2012) Chromatographic fingerprint analysis on flavonoids constituents of the medicinally important plant Aerva lanata $\mathrm{L}$. by HPTLC technique. Asian Pac. J. Trop. Biomed. 8-12. 
Influence of Different Pathways of Regeneration

Shivatare RS, Nagore DH and Nipanikar SU (2013) 'HPTLC' an important tool in standardization of herbal medical product: A review. J. Sci. Innov. Res. 2(6): 10861096.

Shrikumar S, Athem M, Sukumar M and Ravi TK (2005). A HPTLC method for standardization of Curculigo orchioides rhizomes and its marketed formulation using gallic acid as standard. Indian J. Pharm. Sci. 67(6): 721-724.

Singh SR, Dalal S, Singh R, Dhawan AK and Kalia RK (2013) Evaluation of genetic fidelity of in vitro raised plants of Dendrocalamus asper (Schult. \& Schult. F.) Backer ex K. Heyne using DNA-based markers. Acta Physiol. Plant 35(2): 419-430.

Xu JP, Xu RS and Yuli X (1992) Glycosides of cycloartane sapogenin from Curculigo orchioides. J. Phytochem. 31: 233-36.

Yamamoto Y and Richard GB (2001). Therapeutic potential of inhibition of the NF-кB pathway in the treatment of inflammation and cancer. J. Clin. Invest. 107(2): 135-142.

Zietkiewicz E, Rafalshi A and Labuda D (1994) Genome fingerprinting by simple sequence repeat (SSR)-anchored polymerase chain reaction amplification. Genomics 20: $176-183$. 